\title{
MODEL STUKTURAL BERBASIS SISTIM INFORMASI GEOGRAFIS DALAM PENGELOLAAN WILAYAH PESISIR SECARA BERKELANJUTAN
}

\author{
Pieter Th. Berhitu ${ }^{1, *}$ \\ ${ }^{1}$ Jurusan Teknik Mesin Prodi Perencanaan Wilayah dan Kota Fakultas Teknik \\ Universitas Pattimura, Ambon 97233 \\ *Email: patrickberhitu@gmail.com
}

\begin{abstract}
Abstrak. Model Stuktural Berbasis Sistim Informasi Geografis dalam Pengelolaan Wilayah Pesisir Secara Berkelanjutan yang menjadi latar belakang adalah pengelolaan wilayah pesisir kota ambon dan kabupaten Maluku Tengah dalam kurung waktu 10-20 tahun terakhir belum dikelola dengan baik dan berkelanjutan sehingga berbagai aspek pembangunan tidak berjalan dengan baik menyebabkan berbagai permasalahan diantaranya kerusakan lingkunga fisik pesisir yakni abrasi, erosi dan sedimntasi, terjadi kerusakan perairan akibat terjadinya pencemaran, Kerusakan infrastruktur bangunan pelindung, Persoalan mitigasi pesisir, Menurunnya kualitas sumberdaya lingkungan pesisir akibat meningkatnya jumlah penduduk diwilayah pesisir sehingga menyebabkan berkembangnya kawasan - kawasan pemukiman kumuh, Kerusakan ekosistem pesisir. Tujuan penelitian adalah menentukan model dan strategi pengelolaan kawasan pesisir kota Ambon dan Kabupaten Maluku Tengah secara berkelanjutan. Metode yang digunakan dalam penelitian ini adalah metode Deskriptif. Pengambilan Data primer dilakukan dengan kusioner untuk responden dari masyarakat, responden pakar, kelembagaan masyarakat , dan pemangku kebijakan. Analisis yang dilakukan yakni Analisis Keberlanjutan dengan Multi Dimensi Scale (MDS), analisis sistim informasi geografis, analisis struktral SEM, analisis Hirarki Proses (AHP). Hasil analisis keberlanjutan dengan MDS, diperoleh nilai indek keberlanjutan Multi Dimensi sebesar 50,13 \% berada pada katagori cukup berkelanjutan. Hasil analisis model SEM tentang peran zonasi dan peran masyarakat dalam pengelolaan kawasan pesisir berkelanjutan merupakan "fit model" yang dapat diterima. Hasil AHP memberikan gambaran penilaian oleh pemangku kebijakan dalam implementasi program diprioritaskan kepada strategi Manajemen Penataan Kawasan Pesisir Secara Berkelanjutan Berbasis Sistim Informasi Geografis dengan skor penilaian sebesar 39,3 \%, dengan presentasi terbesar adalah "Penataan Kawasan Pesisir Sesuai Perundangan Zonasi Berbasis SIG” sebesar 13,6 \%,
\end{abstract}

Kata kunci: Model structural, sistim informasi geografi, Kota Ambon, Maluku Tengah

\begin{abstract}
Geographical Information System-Based Structural Model in Sustainable Management of Coastal Areas which is the background is that the management of the coastal areas of Ambon City and Central Maluku Regency in the last 10-20 years has not been managed properly and sustainably so that various aspects of development do not work well causing various The problems include damage to the coastal physical environment, namely abrasion, erosion, and sedimentation, water damage due to pollution, damage to protective building infrastructure, coastal mitigation issues, declining quality of coastal environmental resources due to the increasing number of residents in coastal areas, causing the development of slum areas. coastal ecosystem. The purpose of the study is to determine the model and strategy for managing coastal areas in Ambon City and Central Maluku District in a sustainable manner. The method used in this research is the descriptive method. Primary data collection was carried out using a questionnaire for respondents from the community, expert respondents, community institutions, and policymakers. The analysis carried out is Sustainability Analysis with Multi Dimension Scale (MDS), geographic information system analysis, SEM structural analysis, Process Hierarchy analysis (AHP). The results of the sustainability analysis with
\end{abstract}




\begin{abstract}
MDS obtained the Multi-Dimensional Sustainability Index value of 50.13\% is in the moderately sustainable category. The results of the SEM model analysis on the role of zoning and community roles in sustainable coastal area management is an acceptable "fit model". The results of the AHP provide an overview of the assessment by policymakers in the implementation of the program, prioritizing the strategy for Management of Sustainable Coastal Area Management Based on Geographic Information Systems with an assessment score of $39.3 \%$, with the largest presentation being "Coastal Area Arrangement in accordance with GIS-Based Zoning Laws" of 13, 6\%.
\end{abstract}

Keywords: Structural model, geographic information system, Ambon city, Central Maluku

\section{PENDAHULUAN}

Wilayah pesisir dan laut, merupakan aset pembangunan Indonesia yang penting, karena wilayah ini didukung oleh dua komponen utama yaitu komponen biofisik;. dan kedua, adalah komponen sosial ekonomi. Sebagian besar penduduk Indonesia yakni kurang lebih $60 \%$ hidup di wilayah pesisir hal ini disebabkan karena secara administratif, letak pemukiman penduduk pada wilayah pesisir. Data menunjukan bahwa dari 4.028 kecamatan yang ada diindonesia maka 1.129 kecamatan secara topografi terletak di wilayah pesisir, dan dari 62.472 desa yang ada sekitar 5.479 desa merupakan desa-desa pesisir [1]. Wilayah pesisir merupakan salah satu ekosistim yang sangat produktif sehingga perlu dikelola dengan baik. Berbagai aktifitas dan kegiatan manusia pada wilayah pesisir diantaranya aktifitas industri, pertanian, perikanan, permukiman, pertambangan, navigasi, dan pariwisata, seringkali memberikan dampak permasalahan baik pencemaran, kerusakan ekosistem pesisir, sedimentasi dan berbagai permasalahan di wilayah pesisir.

Permasalahan wilayah pesisir kota Ambon dan kabupaten Maluku Tengah dapat dilihat melalui beberapa hasil penelitian yang dilakukan selama kurang lebih 10 tahun terakhir menyimpulkan bahwa telah terjadi a) kerusakan lingkungan fisik pesisir yakni abrasi, erosi dan sedimentasi [2]-[7]; b) telah terjadi kerusakan ekosistem wilayah pesiir yaitu kerusakan hutan mangrove [8]; c) telah terjadi kerusakan padang lamun, alga, dan terumbuh karang [9]; d) penurunan hasil tangkapan ikan umpan [10]; e) terjadi kerusakan perairan akibat terjadinya pencemaran; f) Penurunan jumlah bentos, moluska, krutasea karena pencemaran limbah [11]; g) Kerusakan infrastruktur bangunan pelindung pantai akibat pengaruh alam yakni dinamika gelombang, arus, pasang surut, kenaikan muka air serta aktifitas manusia yakni pengambilan bahan galian c yang tidak terkendali [12], [13]; h) Persoalan mitigasi pesisir, banjir dan tanah longsor [14]; i) Menurunnya kualitas sumberdaya lingkungan pesisir akibat meningkatnya jumlah penduduk diwilayah pesisir sehingga menyebabkan berkembangnya kawasankawasan pemukiman kumuh pada kawasan Mardika, Batumera, Tantui dan Waihayong yang mengakibatkan penurunan kualitas sumberdaya lingkungan pesisir; j) Kerusakan ekosistem pesisir yakni mangrove, terumbu karang dan lamun dengan kriteria rusak indeks ekosistem pesisir berada pada level 44,4 \% [15], menyimpulkan perubahan kondisi ekosistem pesisir disebabkan oleh terjadinya perubahan pemanfaatan lahan di daratan, dimana terjadi penyimpangan pemanfaatan lahan terhadap RTRW Kota Ambon (2011-2030). Penyimpangan pemanfaatan lahan yang cukup siknifikan mempengaruhi pada kondisi terumbu karang adalah konversi lahan hutan dan lahan pertanian menjadi kawasan permukiman (kawasan terbangun) [16]. Konflik penggunaan ruang di wilayah pesisir dan laut Kota Ambon dan Kabupaten Maluku Tengah sering terjadi karena penyimpangan terhadap pola pemanfaatan ruang yang tidak sesuai dengan arahan Rencana Tata Ruang Wilayah [17]. Disamping itu, potensi multiguna yang inherent pada sumberdaya pesisir dan laut menyebabkan banyak pihak yang berupaya untuk memanfaatkannya sehingga menimbulkan konflik pemanfaatan ruang wilayah pesisir [18], [19].

Penelitian yang dilakukan ini secara umum mendukung pencapaian renstra Universitas Pattimura dimana hasil penelitian yang diharapkan berupa model pengelolaan dan kebijakan stategis pengelolaan wilayah pesisir secara berkelanjutan memberikan kontribusi dalam memecahkan secara langsung berbagai permasalahan pembangun melalui kegiatan penelitian kebijakan yang menjawab implementasi visi dan misi Universitas dan bidang keunggulan penelitian yakni pengembangan kelautan dan kepulauan. Temuan dari penelitian ini yang diharapkan untuk pengembnagan ilmu adalah tersediannya model struktural pengelolaan wilayah pesisir berbasis 
sistim informasi geografis serta kebijakan strategis berdasarkan dimensi pembangunan pada wilayah pesisir [20], [21]. Luaran yang ditargetkan yaitu hasil penelitian dapat dipublikasikan pada jurnal nasional terakreditasi dan jurnal internasional.

Berdasarkan latar belakang dan berbagai permasalahan yang terjadi tersebut maka sangat dibutuhkan suatu penelitian tentang "pengelolaan wilayah pesisir secara berkelanjutan melalui pendekatan model struktural berbasis sistim informasi geografis berdasarkan Rencana Tata Ruang Wilayah"

\section{BAHAN DAN METODE}

\subsection{Bahan}

Bahan yang digunakan dalam penelitian ini terdiri dari kusioner penelitian serta tool (software) untuk pengelolaan dan analisis data.

\subsection{Metode Penelitian}

Metode yang digunakan dalam penelitian ini adalah metode deskriptif dimana melalui penelitian terhadap studi kasus pada wilayah pesisir kota Ambon dan Mauku Tengah serta survei untuk menyelesaikan penelitian.

\subsection{Pengolahan dan Analisis Data}

\section{A. Analisis Keberlanjutan dengan Multi Dimensi Scale ( MDS )}

Untuk mengetahui tingkat keberlanjutan pengelolaan wilayah pesisir kota Ambon dan Kabupaten Maluku Tengah yang berdimesi ekologi, ekonomi, sosial budaya, teknologi infrastruktur dan hukum dan kelembagaan maka dilakukan analisis multi dimensi dengan Software MDS. Penghitungan indeks keberlanjutan menggunakan bantuan perangkat lunak Rapfish (Rapid Appraisal for Fisheries) yang dikembangkan oleh Rapfish Group Fisheries Centre University of British Columbia, Canada [22].

MDS pada Rapfish dilakukan dengan menghitung jarak terdekat dari Euclidean distance pada per'samaan (1) berikut [23]:

$$
d_{1,2}=\sqrt{\left(X_{1}-X_{2}\right)+\left(y_{1}-y_{2}\right) 2}
$$

Stress ini dapat dirumuskan dalam persamaan (2) yaitu:

$$
\text { Stress }=\sqrt{\frac{1}{m} \sum_{k=l}^{m}\left[\frac{\sum_{i_{k}\left(D_{i j k}-d_{i j k}\right)^{2}}}{\sum_{i{ }_{k} d_{i j k}}^{2}}\right]}
$$

B. Analisis Struktural Hubungan Antara Faktor Internal dan Faktor Eksternal dalam Pengelolaan Wilayah Pesisir dengan Pemodelan Struktur SEM Amos

Pendekatan model structural dengan Structural Equation Modeling (SEM) AMOS 20.0 [24]. dengan tujuan untuk melihat secara koperhensip bagaimana variable-variabel indenpent dan dependent yang dianalisis terhadap faktor internal dan eksternal dan pengaruh diantara variabel tersebut terhadap keberlanjutan pengelolaan kawasan pesisir kota Ambon dan kabupaten Maluku Tengah

\section{Analytical Hierarchy Process (AHP)}

Perumuskan strategi pengelolaan kawasan pesisir secara berkelanjutan di kota Ambon dan Kabupaten Maluku Tengah, dilakukan dengan pendekatan analisis hierarki Proses melalui hasil analisis SWOT [25]. yang merupakan matriks SWOT yang berisikan atribut strategi dan kebijakan yang mewakili masing-masing faktor kekuatan, kelemahan peluang dan tantang kemudian akan disikronkan dengan hasil pengembangan model dinamik yang berisikan skenario dan kebijakan yang menggambarkan pengembangan dari setiapa atribut yang sensitif mempengaruhi sistem akan menjadi input bagi penentuan prioritas kebijakan dan strategi yang akan diambil dengan menggunakan analisis AHP. Analisis AHP (Analytical Hierarchy Process)

\section{HASIL DAN PEMBAHASAN}

\subsection{Hasil Model Struktural Aspek Peran Zonasi dan Masyarakat Berbasis SIG}

Model aspek peran zonasi dengan konstruk laten $\left(Z_{1}\right)$ memiliki 3 (tiga) indikatornya yaitu; kelestarian sumber daya alam (Y1), daya dukung lingkungan (Y2), dan kesejahteraan masyarakat (Y3). Model aspek peran masyarakat dengan konstruk laten ( $\mathrm{Z}_{1}$ ) juga memiliki 3 (tiga) indicator yaitu; persepsi (Y4), aspirasi (Y5) dan partisipasi (Y6), Kedua variabel endogen ini kemudian dilakukan analisis dengan variabel eksogen (X) melalui Structural Equation Modeling (SEM) AMOS 20.0 
Tabel 1. Regresion Weight Peran Zonasi Berbasis SIG dan Peran Masyarakat

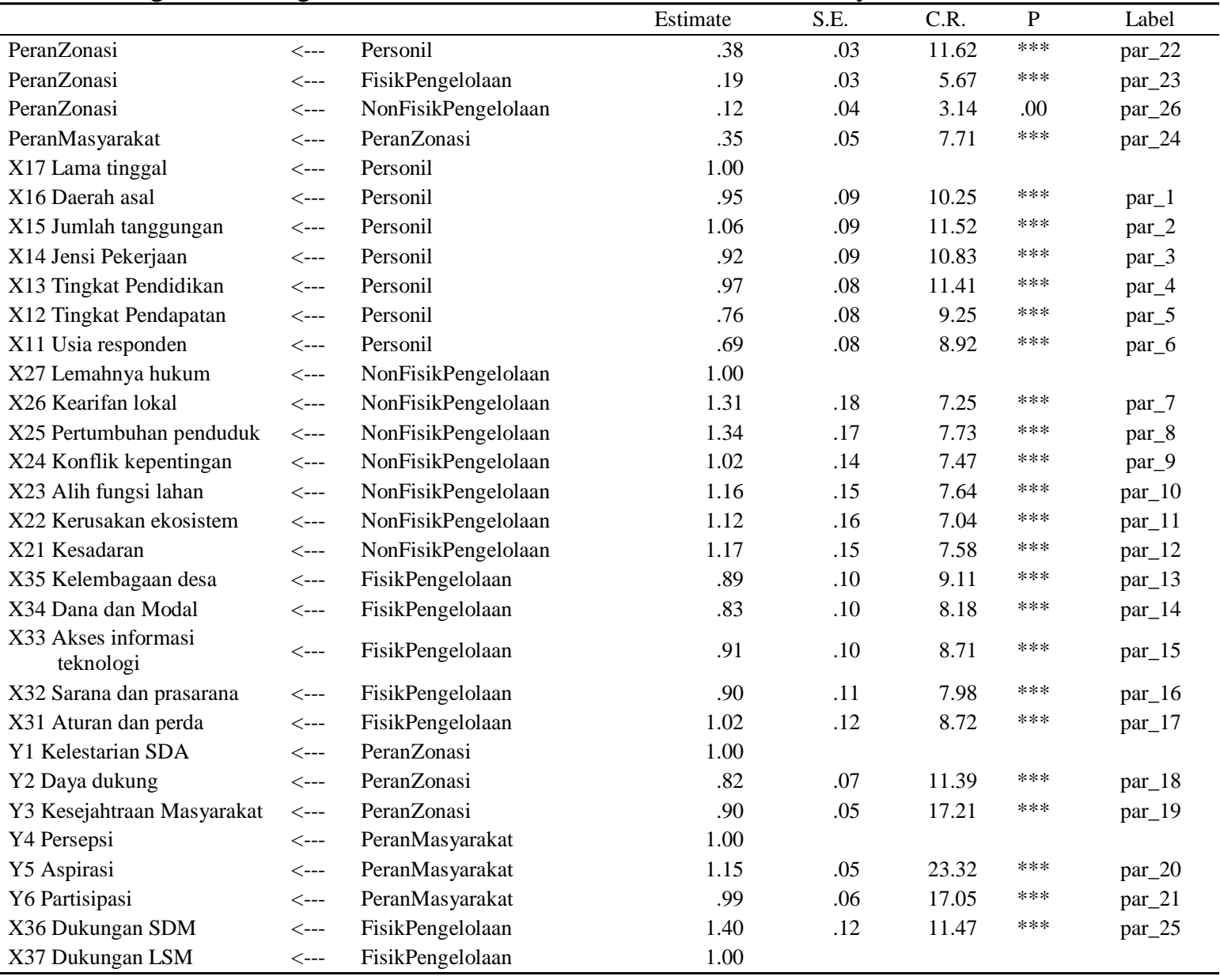

Hasil full model Aspek Peran Zonasi dan Peran Masyarakat menjelaskan bahwa keseluruhan variabel personel pengelolaan (X1), Non Fisik Pengelolaan (X2) dan Fisik pengelolaan (X3) terbukti memberikan pengaruh yang sangat besar (signifikan) terhadap Peran Zonasi (Z1), dengan 3 (tiga) indikatornya yakni kelestarian sumber daya alam (Y1), daya dukung lingkungan (Y2), kesejahteraan masyarakat (Y3). Demikian juga terhadap peran Masyarakat $\left(\mathrm{Z}_{2}\right)$ dengan tiga indikatornya yakni persepsi (Y4), aspirasi (Y5) dan partisipasi (Y6). Untuk melihat seberapa besar bobot pengaruh dari variabel eksogen $(\mathrm{X})$ terhadap variabel endogen $(\mathrm{Y})$ pada aspek peran zonasi dan peran masyarakat dapat dilihat pada Tabel 1 .

Berdasarkan hasil sesuai Tabel 1, terbukti keseluruhan variabel eksogen memiliki nilai probabilitas $(\mathrm{P})$ yang sesuai dengan kriteria $\mathrm{P} \leq$ 0,05 . Selanjutnya tabel diatas juga menjelaskan bahwa rasio kritis (CR) memiliki nilai lebih yaitu 2 (dua) kali dari besaran standart error (SE) yang membuktikan bahwa variabel tersebut Sahih (terbukti valid) telah mampu mengukur apa yang seharusnya diukur pada model. Tabel 1, menjelaskan pengaruh yang signifikan dari keseluruhan indikator kontruk endogen yang ditandai dengan nilai $(* * *)$. Indikator kontsruk endogen terobservasi yang memberikan nilai Critical rasio positif tertinggi adalah Aspirasi Masyarakat (Y5) dengan nilai 23,32 selanjutnya diikuti oleh kesejahteraan masyarakat (Y3) dengan nilai 17,21, Partisipasi masyarakat (Y6) sebesar 17, 05 dan terakhir Daya Dukung sebesar 11,39 (Y2).

Tabel 2. Analisis Faktor Konfirmatori (CFA) Peran Zonasi Berbasis SIG dan Peran Masyarakat

\begin{tabular}{lccc}
\hline Goodness of Fit & $\begin{array}{c}\text { Hasil } \\
\text { Analisis }\end{array}$ & $\begin{array}{c}\text { Cut-off } \\
\text { Value }\end{array}$ & Keterangan \\
\hline$\chi^{2}$ (Chi-Square) & 448,492 & $\begin{array}{c}\text { Diharapkan } \\
\text { kecil }\end{array}$ & Kurang \\
Probability & 0,000 & $\geq 0,05$ & Kurang \\
CMIN & 1,801 & $\leq 2$ & Baik \\
GFI & 0,903 & $\geq 0,90$ & Baik \\
AGFI & 0,883 & $\geq 0,90$ & Marginal \\
TLI & 0,916 & $\geq 0,90$ & Baik \\
NFI & 0,845 & $\geq 0,90$ & Marginal \\
CFI & 0,924 & $\geq 0,95$ & Baik \\
RMSEA & 0,047 & $\leq 0,08$ & Baik \\
\hline
\end{tabular}

Tabel 2 menjelaskan analisis faktor konfirmatori (CFA) melalui hasil Uji goodness of fit yang menggambarkan bahwa secara keseluruhan model penelitian tentang peran zonasi 
dan peran masyarakat dalam pengelolaan kawasan pesisir kota Ambon merupakan "fit model" yang dapat diterima. Hal ini dapat ditunjukan dengan nilai good fitness of fit yang berada diatas kriteria yang ditetapkan seperti diberikan pada Tabel 2 .

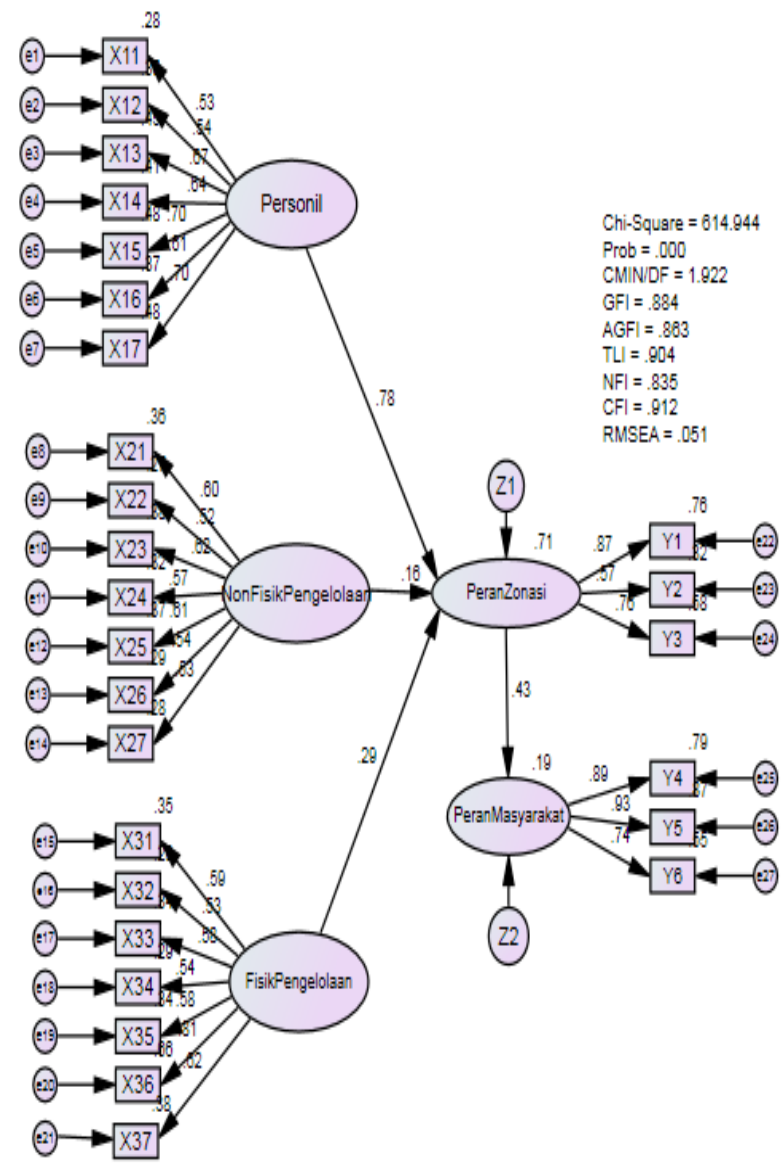

Gambar 1. Model Full Aspek Peran Zonasi Berbasis SIG dan Peran Masyarakat dalam Pengelolaan kawasan Pesisir Kota Ambon Kab Maluku Tengah

Berdasarkan uji Goodnes of Fit sesuai tabel diatas terlihat ada beberapa nilai yang kurang signifikan diantaranya nilai $\chi^{2} \quad(C h i-$ Square),(kurang) Probability (kurang ), AGFI (adjust goodness-of fit), GFI (normed fit index), NFI, (marginal) namun secara keseluruhan model dapat diterima dengan kriteria nilai goodness of fit yang lain seperti RMSEA,CFI, NFI dan CMIN (baik).

\subsection{Hasil Analisis SWOT dan AHP}

Penilaian hasil skoring dari 45 (empatpuluh lima) orang unsur kelembagaam pemerintah dan 30 (tiga puluh) orang unsur kelembagan masyarakat kemudian ditabulasikan yang hasilnya dapat dilihat pada Tabel 3. Berdasarkan tabel 3 dapat dijelaskan bahwa pemberian nilai terendah oleh faktor internal yakni kelembagaan masyarakat asebesar 1,04 yang merupakan hasil pengurangan dari nilai kekuatan (Strenghts) sebesar 4,61 dengan nilai kelemahan (weakness) sebesar 3,45. Untuk faktor eksternal nilai skoring terendah yaitu kelembagaan pemerintah sebesar 0,63 , yang merupakan hasil pengurangan dari nilai kekuatan (strengths) sebesar 4,15 dengan nilai kelemahan (weakness) sebesar 3,52. Hasil dari nilai skor kelembagaan masyarakat dan pemerintah mau menegaskan bahwa secara eksternal apabila masyarakat diperhadapkan dengan berbagai tantangan, dan ancaman yang ada maka masyarkat lebih bersifat optimis menghadapinya jika dibandingkan dengan pemerintah walaupun secara internal masyarakat pesimis dengan kekuatan dan kelemahan yang dimilikinya. Hasil sesuai tabel 3 menjelaskan nilai rataan bobot gabungan secara internal maupun eksternal antara kelembagaan pemerintah dan kelembagaan masyarakat dapat dibuat visualisasi dalam kuadran hasil SWOT seperti terlihat pada Gambar 2. Dari gambar tersebut dapat dilihat bahwa titik hasil perhitungan SWOT terletak pada Kuadran I yang menunjukan nilai kekuatan (S) dan peluang (O) yang keduanya mempunyai nilai yang positif.

Berdasarkan nilai rataan dari kekuatan (strengths) dan peluang (opportunity) yang positif, maka menutur Fleisher dan Bensoussan (2006), mengatakan bahwa strategi organisasi yang berhubungan dengan kekuatan internal organisasi dan peluang eksternal organisasi yang demikian merupakan kesesuaian yang terbaik. Dari hasil ini menjelaskan bahwa strategi dari kuadrat SWOT I merupakan strategi yang secara ekspansi akan melindungi kekuatan organiasi dengan menopang kepada seluruh sumber daya dan dana yang ada dan selanjutnya mampu memperluas keunggulan secara kompetitif dan berkesinambungan sehingga mampu bersaing dan mampu membaca peluang untuk kepentingan organisasi.

\section{Tabel 3. Hasil Skoring Analisis SWOT}






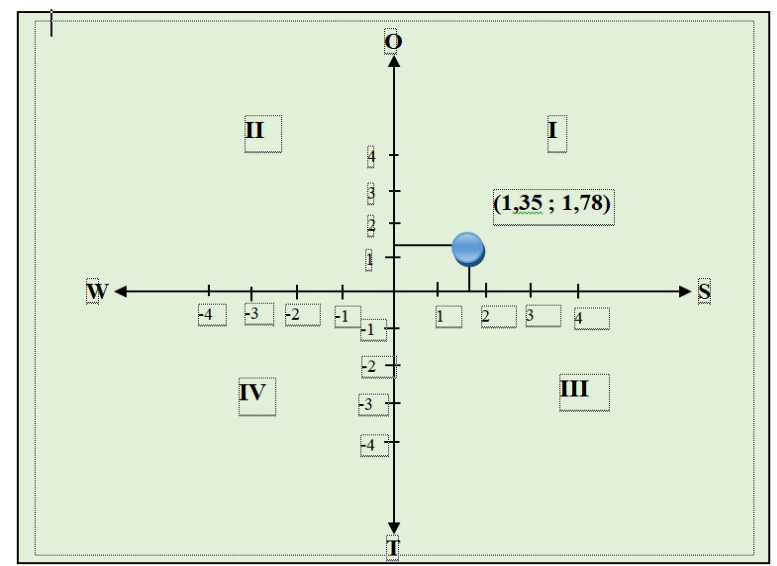

Gambar 2. Visualisasi koordinat hasil perhitungan SWOT

\subsection{Analytical Hierarchy Process (AHP)}

Selanjutnya keduapuluh empat formulasi strategi tersebut kemudian diolah untuk memperoleh kriteria-kriteria alternatif yang kemudian oleh peneliti dikelompokan menjadi 5 (lima) kriteria utama dalam analisis AHP yaitu;

1. Manaemen Pengendalian Kerusakan Sumber

Daya Pesisir (MANPSDKP)

2. Manajemen Penataan Kawasan Pesisir

(MANPKAWP)

3. Manajemen Konservasi Kawasan Pesisir (MANKONP)

4. Manajemen Kelembagaan Pengelolaan $r$ (MANKELP)

5. Pemberdayaan Aspek sosial,dan kearifan lokal Masyarakat (PASKLMSY)

Berdasarkan 5 (lima) kriteria utama yang dibentuk sesuai dengan tujuan utama, maka kelima kriteria utama sesuai tujuan penelitian ini kemudian dikelompokan menjadi unsur-unsur alternatif yang akan dinilai berdasarkan ketentuan AHP, salah satunya diformulasikan sebagai berikut:

Manajemen Pengendalian Kerusakan Sumber Daya Pesisir (MANPSDKP) dengan alternative;

1. Sosialisasi dan Penyuluhan tentang pengendalian Kerusakan bagi Masyarakat (SOSPENGK)

2. Penerapan aturan Hukum dan Sangsi (PENATSAN)

3. Pelarangan Terhadap Eksploitasi Sumber Daya Pesisir (PELUEKSP)

4. Peningkatan Kapasitas Sumber Daya (PENKAPSD)

5. Pembentukan Kelompok Masyarakat Sadar Lingkungan (PENKAPSD)

Unsur utama yang merupakan kriteria utama didalam AHP, selanjutnya akan disusun berdasarkan kerangka AHP dengan memuat unsur- unsur aternatif sesuai dengan hasil SWOT. Gambar 3, memberikan gambaran tentang kerangka hierarkhi struktur AHP.

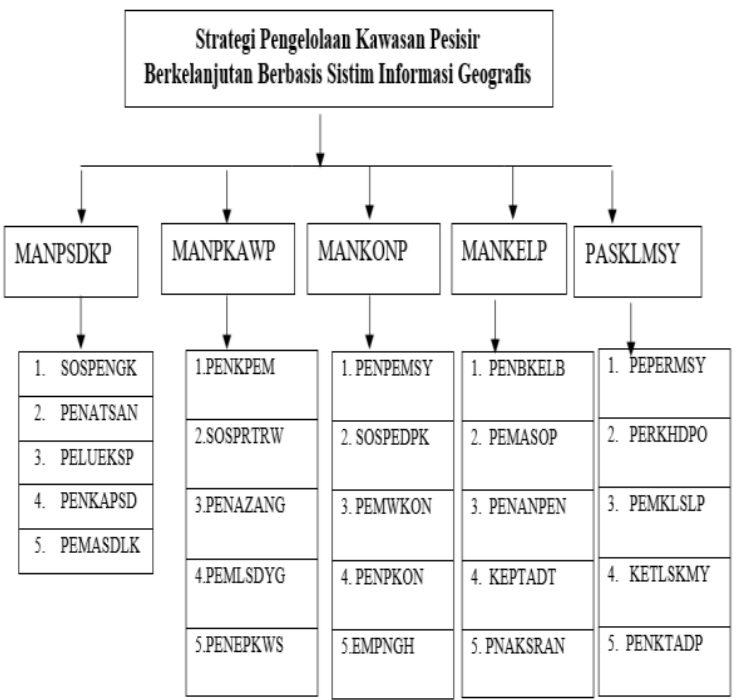

Gambar 3. Model AHP

Tabel 4. Hasil Skoring Penilaian Kriteria dan Alternatif Kriteria AHP

\begin{tabular}{|c|c|c|c|c|}
\hline No & $\begin{array}{c}\text { Kriteria Utama dan } \\
\text { Alternatif Kriteria } \\
\text { Kriteria Utama }\end{array}$ & Kode & $\begin{array}{c}\text { Nilai } \\
\text { PC }\end{array}$ & Ranking \\
\hline 1 & $\begin{array}{l}\text { Manajemen Penataan } \\
\text { Kawasan Pesisir }\end{array}$ & MANPKAWP & $39,3 \%$ & 1 \\
\hline 2 & $\begin{array}{l}\text { Manajemen Pengendalian } \\
\text { Kerusakan Sumber Daya } \\
\text { Pesisir }\end{array}$ & MANPSDKP & $22,1 \%$ & 2 \\
\hline 3 & $\begin{array}{l}\text { Manajemen Konservasi } \\
\text { Kawasan Pesisir }\end{array}$ & MANKONP & $17,1 \%$ & 3 \\
\hline 4 & $\begin{array}{l}\text { Manajemen Kelembagaan } \\
\text { Pengelolaan Kawasan } \\
\text { Pesisir }\end{array}$ & MANKELP & $11,8 \%$ & 4 \\
\hline 5 & $\begin{array}{l}\text { Pemberdayaan Aspek } \\
\text { sosial,dan kearifan lokal } \\
\text { Masyarakat }\end{array}$ & PASKLMSY & $9,6 \%$ & 5 \\
\hline & Alternatif Kriteria Strate & & & \\
\hline 1 & $\begin{array}{l}\text { Penataan Kawasan Sesuai } \\
\text { Perundangan Zonasi } \\
\text { Berbasis Sistim Informasi } \\
\text { Geografis }\end{array}$ & PENAZANG & $13,6 \%$ & 1 \\
\hline 2 & $\begin{array}{l}\text { Penerapan dan Sosialisasi } \\
\text { RTRW K }\end{array}$ & SOSPRTRW & $10,9 \%$ & 2 \\
\hline 3 & $\begin{array}{l}\text { Sosialisasi Dan } \\
\text { Penyuluhan Tentang } \\
\text { Pengendalian Kerusakan } \\
\text { Bagi Masyarakat }\end{array}$ & SOSPENGK & $8,9 \%$ & 3 \\
\hline 4 & $\begin{array}{l}\text { Peningkatan Peran } \\
\text { Masyarakat Adat dan } \\
\text { kearifan lokal }\end{array}$ & PENPEMSY & $7,1 \%$ & 4 \\
\hline 5 & $\begin{array}{l}\text { Penataan Kawasan } \\
\text { Pemukiman, Industri, } \\
\text { Bisnis, Parawisata dan } \\
\text { lainnya }\end{array}$ & PENKPEM & $7,0 \%$ & 5 \\
\hline 6 & $\begin{array}{l}\text { Penerapan Aturan Hukum } \\
\text { dan Sangsi }\end{array}$ & PENATSAN & $4,9 \%$ & 6 \\
\hline 7 & $\begin{array}{l}\text { Pemanfaatan Lahan } \\
\text { Sesuai daya dukung }\end{array}$ & PEMLSDYG & $4,5 \%$ & 7 \\
\hline 8 & $\begin{array}{l}\text { Penataan Birokrasi dan } \\
\text { sistem informasi }\end{array}$ & PENBKELB & $4,3 \%$ & 8 \\
\hline 9 & $\begin{array}{l}\text { Sosialisasi dan } \\
\text { Penyuluhan Dampak } \\
\text { Lingkungan }\end{array}$ & SOSPEDPK & $3,9 \%$ & 9 \\
\hline
\end{tabular}


Sesuai Tabel 4, maka kriteria utama Manajemen Penataan kawasan Pesisir merupakan rangking 1 sebear $39,3 \%$ dan diperoleh alternatif kriteria dengan rangking yang tertinggi adalah penatan kawasan sesuai dengan perundangan zonasi berbasis Sistim Informasi geografis sebesar $13,6 \%$. Hal ini sesuai dengan hasil FGD yang merekomendasikan bahwa penataan kawasan untuk berbagai aktifitas dan kepentingan pada kawasan pesisir harus berdasarkan kepada perencanaan zonasi berbasis sistim informasi geografis Alternatif kriteria dengan rangking yang rendah adalah sosialisasi dan penyuluhan dampak lingkungan sebesar 3,9 \%. Dengan melihat rangking alternatif kriteria tertinggi maka ditegaskan bahwa pemerintah Kota harus mempersiapkan perencanaan zonasi kawasan pesisir dalam upaya pengelolaan kawasan pesisir secara berkelanjutan di kota Ambon. Hasil AHP secara lengkap dapat dilihat pada Tabel 4 dan Gambar 3.

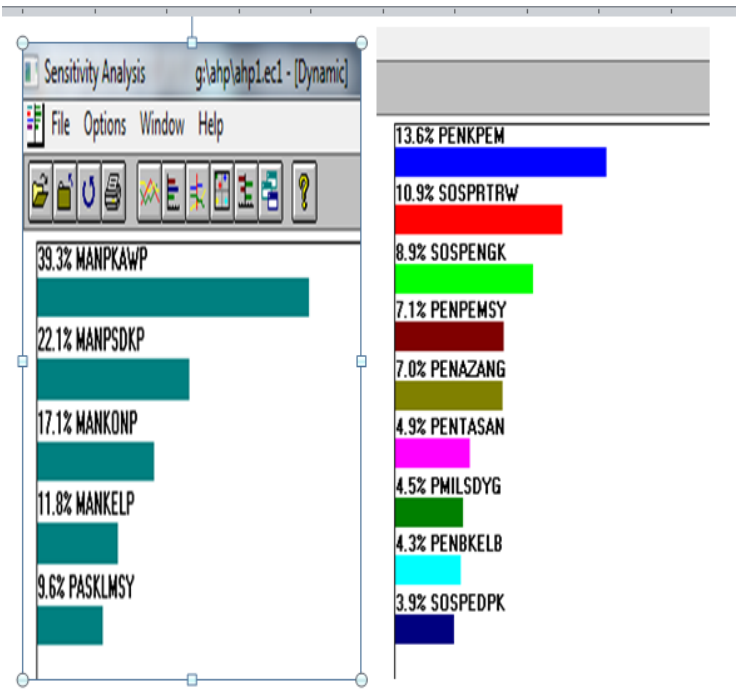

Gambar 3. Grafik Dinamik Sensitifitas

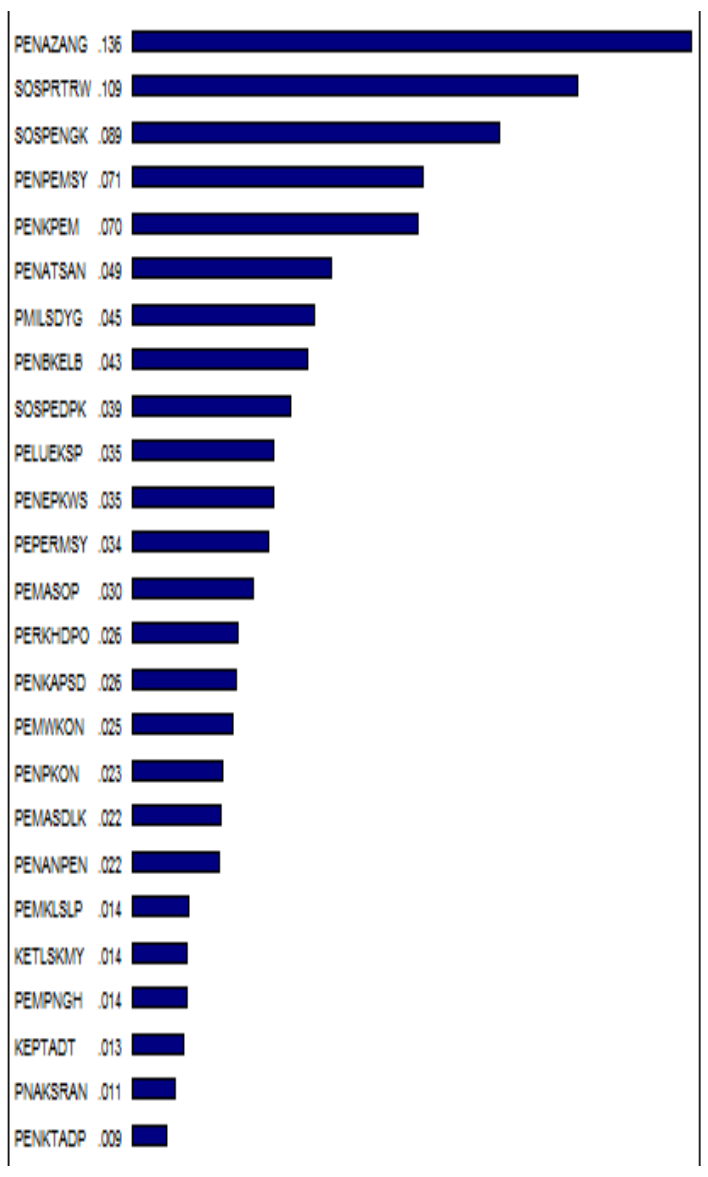

Gambar 4. Hasil distribusi rangking alternatif kriteria Strategi Pengelolaan Kawasan Berkelanjutan Berbasis SIG

\subsection{Hasil Penggunaan Lahan Kota Ambon dan Maluku Tengah}

Berdasarkan hasil pemetaan lahan kota Ambon terhadap 5 kecamatan maka dapat disimpulkan untuk;

1. Kecamatan Nusaniwe; Luas tutupan lahan untuk pemukiman $=6,44 \mathrm{Km} 2 .(13,43 \%)$, Vegetasi/Hutan $=41.51 \mathrm{Km} 2(86,57 \%)$

2. Kecamatan Sirimau; Luas tutupan lahan untuk pemukiman $=10,45 \mathrm{Km} 2 . \quad(32 \%)$, Vegetasi/Hutan $=22,05 \mathrm{Km} 2(68 \%)$

3. Kecamatan Teluk Ambon; Luas tutupan lahan untuk pemukiman $=5,9 \mathrm{Km} 2 .(6 \%)$, Vegetasi $=92,05 \mathrm{Km} 2(83,8 \%)$

4. Kota Masohi, Luas tutupan lahan untuk pemukiman $=4,154 \mathrm{Km} 2(79 \%)$, vegetasi $=$ $1,058 \mathrm{Km} 2(20 \%)$ 

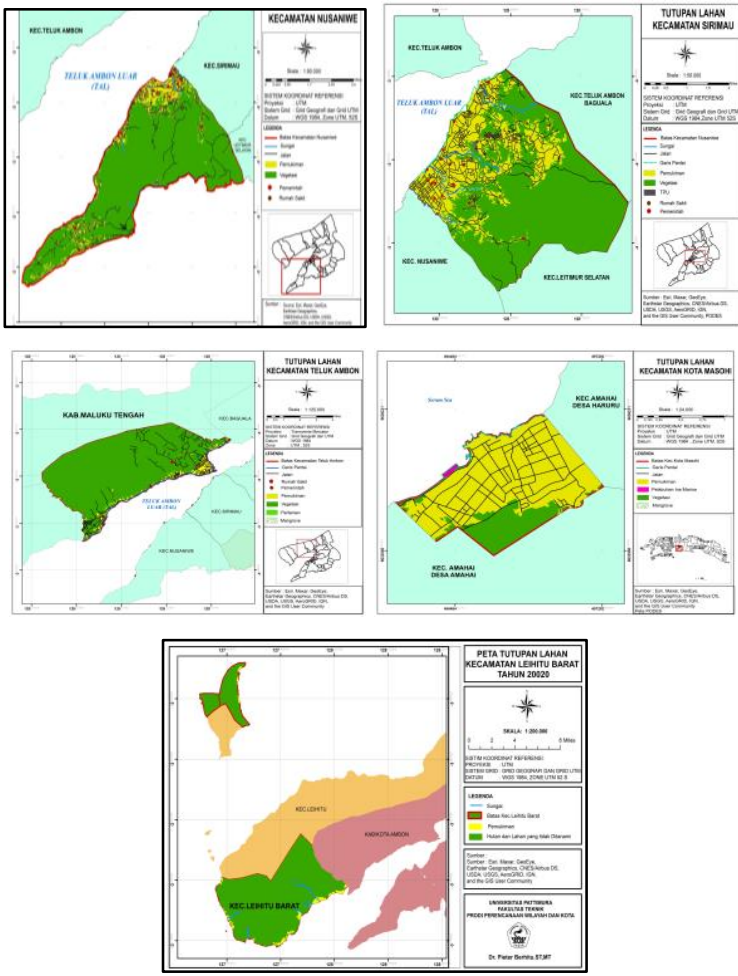

Gambar 5. Penggunaan Lahan Kota Ambon dan Maluku Tengah

Dengan memperhatikan Tutupan lahan kota Ambon dan Maluku Tengah maka dapat disimpulkan penggunaan lahan setiap tahun mengalami perubahan karena berbagai aktifitas penduduk dan pembangunan mengingat pertumbuhan penduduk menjadi salah satu pertimbangan penting sebagai konsuekuensi penggunaan lahan terkait dengan pertambahan lahan untuk kebutuhan pemukiman penduduk.

\subsection{Hasil Analisis Multi Dimensi (MDS)}

Berdasarkan hasil analisis MDS secara keseluruhan terhadap 5 dimensi keberlanjutan pengelolaan kawasan pesisir kota Ambon yakni ekologi, ekonomi, sosial budaya, teknologi dan infrastruktur, serta hukum dan kelembagaan maka diperoleh nilai indek keberlanjutan Multi Dimensi sebesar $50,13 \%$ berada pada katagori "cukup berkelanjutan". Nilai indeks masing-masing dimensi dapat dilihat pada Tabel 5. Selanjutya untuk atribut yang sensitif pada setiap dimensi berdasarkan hasil analisis leverage factor dengan mengacu pada nilai RMS diperoleh 12 atribut. Hasil analisis juga diperoleh perbandingan hasil analisis Monte Carlo dengan MDS sangat kecil, seperti pada Tabel 6-8. Perbedaan antara hasil analisis MDS dan Monte Carlo menunjukkan adanya kesalahan yang kecil dan memberikan perubahan pada indeks keberlanjutan dimensi yang dianalisis. Berdasarkan hasil analisis terhadap 5 dimensi tersebut, maka indeks keberlanjutan secara keseluruhan dapat dilihat pada diagram layang sesuai Gambar 6 .

Hasil analisis Multi-Dimensional (MDS) dan analisis Monte Carlo juga memperlihatkan pengaruh galat dengan tingkat kesalahan pada taraf kepercayaan 95 persen dengan nilai stress berkisar antara 0,14 sampai 0,15 (ketentuan nilai stress < $0,25)$. Nilai determinasi $\left(\mathbf{R}^{2}\right)$ berkisar 0,94 sampai 0,95 (ketentuan nilai $\mathbf{R}^{2}$ mendekati 1,0 ). Dengan demikian dapat disimpulkan bahwa hasil analisis MDS ini dapat dipakai untuk mengetahui tingkat keberlanjutan pengelolaan kawasan pesisir kota Ambon dan Maluku Tengah secara berkelanjutan dengam model struktural berbasis SIG.

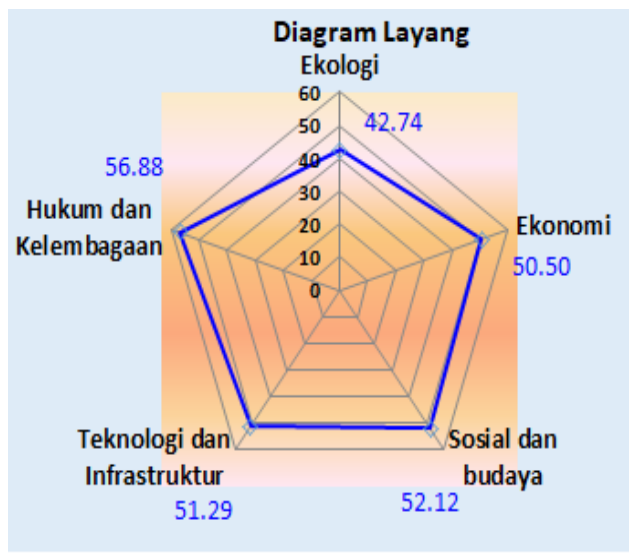

Gambar 6. Diagram Layang

Tabel 5. Nilai Indeks Keberlanjutan untuk Multi Dimensi

\begin{tabular}{lcc}
\hline \multicolumn{1}{c}{ Dimensi } & $\begin{array}{c}\text { Nilai Indeks } \\
\text { Keberlanjutan }\end{array}$ & Keterangan \\
\hline Ekologi & 42.74 & Kurang Berkelanjutan \\
Ekonomi & 50.50 & Cukup Berkelanjutan \\
Sosial-Budaya & 52,12 & Cukup Berkelanjutan \\
Teknologi dan & 51,29 & Cukup Berkelanjutan \\
Infrastruktur & & \\
Hukum dan & 56,88 & Cukup Berkelanjutan \\
Kelembagaan & & Cukup Berkelanjutan \\
Multi Dimensi & $\mathbf{5 0 , 1 3}$ & \\
\hline
\end{tabular}


Tabel 6. Atribut Yang Sensitif

\begin{tabular}{|c|c|c|c|c|}
\hline \multicolumn{5}{|c|}{ Dimensi } \\
\hline Ekologi & Ekonomi & Sosial Budaya & $\begin{array}{l}\text { Teknologi dan } \\
\text { Infrastruktur }\end{array}$ & Hukum dan Kelembagaan \\
\hline $\begin{array}{l}\text { a. Tingkat kerusakan } \\
\text { fisik pesisir } \\
\text { b. Tingkat kesesuaian } \\
\text { lahan } \\
\text { c. Tingkat kerusakan } \\
\text { ekosistem pesisir }\end{array}$ & $\begin{array}{l}\text { a. } \text { Kontribusi } \\
\text { sektor } \\
\text { parawisata } \\
\text { b. Pendapatan asli } \\
\text { daerah } \\
\text { c. Pemasaran hasil } \\
\text { perikanan }\end{array}$ & $\begin{array}{l}\text { a. peran kearifan lokal } \\
\text { b. Tingkat pengetahuan } \\
\text { serta partisipasi } \\
\text { masyarakat dalam } \\
\text { pengelolaan sumber } \\
\text { daya alam }\end{array}$ & $\begin{array}{l}\text { a. Dukungan sarana } \\
\text { prasarana industri } \\
\text { kecil dan } \\
\text { menengah } \\
\text { b. Dukungan sarana } \\
\text { dan prasarana } \\
\text { parawisata }\end{array}$ & $\begin{array}{l}\text { a. Peraturan tentang } \\
\text { pengelolaan pesisir dan } \\
\text { sumber daya alam } \\
\text { b. Implementasi aturan } \\
\text { SASI dalam pengelolaan } \\
\text { sumber daya Alam. }\end{array}$ \\
\hline
\end{tabular}

Tabel 7. Hasil analisis Montecarlo

\begin{tabular}{lccc}
\hline \multicolumn{1}{c}{ Dimensi } & \multicolumn{2}{c}{ Nilai Indeks Perbedaan } & \multirow{2}{*}{ Perbedaan } \\
\cline { 2 - 3 } \multicolumn{1}{c}{ MDS } & Monte Carlo & \\
\hline Ekologi & 42.74 & 42,69 & 0.05 \\
Ekonomi & 50,50 & 50,43 & 0,07 \\
Sosial Budaya & 52,12 & 51,84 & 0,28 \\
Teknologi dan & 51,29 & 50,99 & 0,30 \\
Infrastruktur & & & \\
Hukum dan & 56,88 & 56,50 & 0,38 \\
Kelembagaan & & & \\
Multi-dimensi & $\mathbf{5 0 . 1 3}$ & $\mathbf{5 0 , 0 2}$ & $\mathbf{0 , 1 1}$ \\
\hline
\end{tabular}

Tabel 8. Nilai Stress dan $\mathrm{R}^{2}$

\begin{tabular}{lccccc}
\hline & \multicolumn{5}{c}{ Dimensi } \\
\cline { 2 - 6 } Parameter & Ekologi & Ekonomi & $\begin{array}{c}\text { Sosial } \\
\text { dan } \\
\text { Budaya }\end{array}$ & $\begin{array}{c}\text { Teknologi } \\
\text { Infrastruktur }\end{array}$ & $\begin{array}{c}\text { Hukum dan } \\
\text { Kelembagaan }\end{array}$ \\
\hline Stress & 0,15 & 0,14 & 0,15 & 0,15 & 0,14 \\
$\mathrm{R}^{2}$ & 0.95 & 0,95 & 0,95 & 0,95 & 0,95 \\
\hline
\end{tabular}

\section{KESIMPULAN}

Dari penelitian ini dapat ditarik kesimpulan:

1. Tingkat keberlanjutan pengelolaan kawasan pesisir kota Ambon dan Kab Maluku Tengah secara keseluruhan (multi dimensi) adalah sebesar $50,13 \%$, berada pada status cukup berkelanjutan.

2. Model structural berbasis SIG hubungan peran zonasi berbasis sistim informasi geografis (Y1 - Y3) serta peran masyaraka (Y4 - Y6) dalam pengelolaan kawasan pesisir secara berkelanjutan sangat dipengaruhi oleh faktor personel pengelolaan (X1), Non Fisik Pengelolaan (X2) dan Fisik pengelolaan (X3), Keseluruhan variabel eksogen memiliki nilai probabilitas $(\mathrm{P})$ yang sesuai dengan kriteria $\mathrm{P} \leq$ 0,05 , dan nilai rasio kritis $(\mathrm{CR})$ memiliki nilai lebih yaitu 2 (dua) kali dari besaran standart error (S.E) yang membuktikan bahwa variabel tersebut sahih (terbukti valid) telah mampu mengukur apa yang seharusnya diukur pada model.

3. Penilaian hasil analisis SWOT kelembagaan pemerintah dan masyarakat terhadap kekuatan (strengths), kelemahan (weakness), peluang (opportunity) dan ancaman (threaths) berada pada kuadran I (pertama) visualisasi hasil SWOT dengan nilai $(1,35$; dan 1,8$)$. Hasil Analisis SWOT pengelolaan kawasan pesisir kota Ambon berkelanjutan berbasis zonasi kemudian dilakukan analisis melalui AHP memberikan gambaran bahwa penilaian oleh pemangku kebijakan dalam implementasi program diprioritaskan kepada strategi "Manajemen Penataan Kawasan Pesisir Secara Berkelanjutan Berbasis Sistim Informasi Geografis" dengan skor penilaian sebesar $39,3 \%$. Terdapat 9 (sembilan) alternatif kriteria strategi yang harus dijalankan sesuai dengan tiga prioritas utama berdasarkan urutan yakni "Penataan Kawasan Pesisir Sesuai Perundangan Zonasi Berbasisi SIG" sebesar 13,6 \%, kemudian "Penerapan dan Sosialisasi RTRW Kota Ambon" sebesar 10,9\% dan terakhir adalah "Sosialisasi dan Penyuluhan Tentang Pengendalian Kerusakan Bagi Masyarakat" di kota Ambon maupun di Kabupaten Maluku Tengah sebesar 8,9\%.

\section{DAFTAR PUSTAKA}

[1] R. Dahuri, J. Rais, S.Ginting dan J. Sitepu, (2004). Pengelolaan Sumber daya Wilayah Pesisir dan Lautan Secara Terpadu. PT Pradnya Paramita. Jakarta

[2] P. Berhitu (2007). Studi Kerusakan Garis Pantai Teluk Ambon Luar Dan Pengaruhnya Terhadap Tata Ruang Wilayah Kota Ambon. Prosiding Seminar Nasional Teknologi Kelautan. ITS . 243-249

[3] S. Helvina (2014). Pengaruh Deposional Terhadap Daya Dukung Lingkungan Perairan Teluk Ambon Bagian Dalam Untuk Pengembangan Keramba Jaring. Tesis S2 (tidak dipublikasikan). Program Pasca Sarjana Ilmu Lingkungan

[4] H. Lekatompessy, M. Djafar Saidi, dan A Tuwo (2012). Tanggung Jawab Pemerintah Kota Ambon Dalam Menangani Pemukiman Yang Berdampak Terhadap Lingkungan Pesisir Lateri Ambon. Jurnal Managemen Lingkungan 12 (2) 1-14

[5] F. Leuwol (2007). Pengaruh Sedimen Sungai Galala Terhadap Garis pantai Di Perairan Teluk Ambon. Tesis S2 (tidak dipublikasikan) 
Program Pasca Sarjana Universitas Gaja Mada

[6] S. Tuhumury, Uneputty, P. A dan Tupan, Ch. I. (2008). Sedimentasi dan Ekosistem Mangrove di sungai wairekang, Lateri Ambon. J. Ichthyos, 8 (2) : 87- 94

[7] T. J. Kakisina, (2009). Estimasi Efektifitas Penggunaan Groin Untuk Mengatasi Erosi Pada Kawasan Pesisir Pantai Utara Teluk Baguala Ambon. Jurnal Teknologi. 6 (2) 703 707

[8] J. Abrahamsz, dan M.A Tuapatinaja, (2005). Evaluasi Kawasan Konservasi Hutan Mangrove di Desa Passo. Jurnal Ichtyos, 4 (2): $93-98$

[9] D. A. J. Selanno, A. S Julian, dan P. Beruat, (2008). Analisis Tingkat Kerusakan Mangrove di teluk Ambon Dalam. Jurnal Penelitian Perikanan, 8(1): 23-2

[10] A. J. Debby, E. M. Adiwilaga, R. Dahuri, M. Ismudi, dan H. Effendi (2009). Sebaran Spasial Luasan Area Tercemar dan Analisis Beban Pencemaran Bahan Organik Pada Perairan Teluk Ambon Dalam. Jurnal Torani 19 (2): $96-106$

[11] D. A. Sihasale (2013). Keanekaragaman Hayati Di Kawasan Pantai Kota Ambon Dan Konsekuensi Untuk Pengembangan Pariwisata Pesisir. Journal of Indonesian Tourism and Development Studies, 1(1) 20 27

[12] P. Berhitu, dan Y. Matakupan (2010). Kajian Kelayakan Pengembangan Kawasan Pesisir Kota Ambon Sebagai Kota Pantai, Jurnal Teknologi dan Sains, 7(1):767-781

[13] I. Idris (2010). Penataan kelembagaan dalam pengelolaan sumberdaya pesisir dan kelautan: studi kasus di Teluk Ambon dalam, Kotamadya Daerah Tingkat II Ambon, Tesis Sekolah Pasca Sarjana Universitas Indonesia, 78-81

[14] P. Berhitu, W. Latuny dan M. Efruan. (2010). Preliminary Feasibility Study And Development Coastal Region of Ambon City as Ambon Water Front City in Supporting Potentials and Regional Competitiveness. Proceding International Conference on Marine Technology, Bangladesh Dacha, 6772

[15] A. Yulia (2008). Pengaruh Pemanfaatan Lahan Terhadap Ekosistem Pesisir Dikawasan Teluk Ambon, Jurnal Wilayah dan Kota 12:15-25

[16] Badan Perencanaan Pembangunan Kota (Bappekot) Ambon Kota Ambon (2019).
RTRW Kota Ambon (20013-2031). Penerbit Bappekot Ambon

[17] Badan Perencanaan Pembangunan Kabupaten Maluku Tengah 2008 - 2028 , Rencana Strategis Maluku Tengah 2018

[18] Badan Perencanaan Pembangunan Kota (Bappekot) Ambon Kota Ambon (2012). Rencana Strategis Kota Ambon 2012 - 2032

[19] Ditjen KP3K. (2019). Pedoman Penyusunan Rencana Zonasi Kawasan Pesisir dan Laut. Edisi ke II. Departemen Kelautan dan Perikanan.

[20] Dulbahri (2001). Sistem Informasi Geografis. Penginderaan Jauh Untuk Sumberdaya dengan Pendekatan Intepretasi Citra dan Survei Terpadu, Universitas Gadjah Mada Fakultas Geografi (PUSPICS) UGMBakorsutanal, Yogyakarta.

[21] ESRI, (1999). GIS for School and Libraries Version 5, Environmental Research Institute

[22] P. Kavanagh (2001). Rapid Appraisal of Fisheries (Rapfish) Project. Rapfish Software Description (for Microsoft Exel). University of British Columbia.

[23] P. Kavanagh, dan T. J. Pitcher (2004). Implementing Microsoft Excel Software for RAPFISH: A Technique for The Rapid Appraisal of Fisheries Status. The Fisheries Centre, University of British Columbia, 2259 Lower Mall Vancouver, Canada, V6T IZ4

[24] Wijaya dan Mustafa (2012). Panduan Teknik Statistik SEM Dan PLS Dengan SPSS AMOS. Konsep dasar SEM dan PLS: Pengenalan Amos dan

[25] F. Rangkuti (2009). Analisis SWOT Teknik Membelah Kasus Bisnis, Reorentasi Konsep Perencanaan Strategis Untuk Menghadapi Abad 2001. PT Gramedia Pustaka Utama Jakarta $188 \mathrm{hlm}$. 